\title{
Chapter 1 \\ Defining the Concept of Brand Equity With Radical Transparency
}

\author{
Elena Veselinova \\ Goce Delčev University of Štip, Macedonia \\ Marija Gogova Samonikov \\ Goce Delčev University of Štip, Macedonia
}

\begin{abstract}
Every company must seek the formula that works best for its particular culture and industry. There is no one right way to transform a conventional company into a value driven company. But all the authentically responsible companies subscribe to a set of principles about: the mission, vision, transparency, working, responsibility, openness, authenticity and innovation - all this put in an agenda for value driven companies which are prepared for the challenges we all face. This chapter analyses how the transformational forces: the tangible worth of intangible assets, the war for top-grade talent, the impressive power of inspired employees, the transparent supply chains, the global impact of NGOs, the informed global consumer reshape the business landscape. The insurgent companies that seize on these drives will create real value and increase their long-term profitability. The concept of radical transparency in business gives the companies the opportunity to win the battle for success differently from the competitors, which would ensure the company's sustainable growth and profitability, arousing from the well-shaped relationships with the stakeholders who provide value for the company. The company's brand would be a synonym for those connections.
\end{abstract}

\section{INTRODUCTION}

The tangible worth of intangible assets, the war for top-grade talent, the impressive power of inspired employees, the transparent supply chains, the global impact of NGOs, the informed global consumerall these transformational forces reshape the business landscape. The insurgent companies that seize on these drives will create real value and increase their long term profitability.

DOI: 10.4018/978-1-5225-9282-2.ch001

Copyright $\odot$ 2020, IGI Global. Copying or distributing in print or electronic forms without written permission of IGI Global is prohibited. 
The concept of radical transparency lays in the basics of a vision of a better business, one that operates in greater harmony with its environment and offers a more exciting and meaningful place to work. The vision blends principles and practices-like understanding the challenges that come with creating a sense of purpose and what it takes to integrate that mission into an enterprise's day-to-day work. The key is to keep building capability along dimensions, increasing genuine commitment and the skills to deliver on that commitment.

A small number of corporations are starting to internalize the truly strategic implications of the changes that are looming, but even these few leading enterprises are far from truly integrating an expansive business mission into their daily operations. The following two things can shift this state of affairs: a different vision of the future that is more inspiring than the actual status quo, and a new consensus on what it will take to move toward it.

Every company must seek the formula that works best for its particular culture and industry. There is no one right way to transform a conventional company into a value driven company. But all the authentically responsible companies subscribe to a set of principles about: the mission, vision, transparency, working, responsibility, openness, authenticity and innovation - all this put in an agenda for value driven companies which are prepared for the challenges we all face. Responsible companies believe that what they stand for - their purpose and values are far more important than the products they make or services they sell. For them, advocacy is a synonymous with strategy - the industry needs a reform and they aim to fix it. When companies stand for something big, something that truly matters to people, they sharply differentiate themselves from their competitors.

In the future, companies will fight a battle for brand dominance. Investors will recognize the brand as the most important asset of companies. This is a critical concept. This is a vision of how to develop, manage, strengthen and define the business. It will be more important to own markets than to own resources. And the only way to own the market is to have a dominant brand. The concept of radical transparency in business gives the companies the opportunity to win the battle for success differently from the competitors, which would ensure the company's sustainable growth and profitability, arousing from the well-shaped relationships with the stakeholders who provide value for the company. The company's brand would be a synonym for those connections.

\section{ADOPTING THE IDEA OF RADICAL TRANSPARENCY IN BUSINESS}

History has shown that the world has faced many challenges in many different ways. The economy has put a lot of people out of work in different part of the world in different time interval. But the difficulties people suffered are always the same. The extraction and usage of resources has led and, yet, leads to growing climate crisis and changes with catastrophic possibilities, and the costs for the current lifestyle that the future generations will bear are incredibly huge. As dramatic as the past has been, it only announces the economic, social, political and environmental turbulence yet to come. According to the World Wildlife Fund, if China alone were to reach the rate of U.S. consumption, in terms of natural resources extracted and ecosystems impacted, we would need the equivalent of two Earths. The consequences of such excess and the resultant degradation disproportionately increase the unequal distribution of wealth worldwide. Today, on the one side, half of world's wealth is in the hands of $1 \%$ of the population (The Guardian, 2017, January 16) and on the other, approximately one billion people do not have reliable access to clean drinking water. Clearly, the world is still away from reducing the enormous economic, 
15 more pages are available in the full version of this document, which may be purchased using the "Add to Cart" button on the product's webpage: www.igi-global.com/chapter/defining-the-concept-of-brand-equity-withradical-transparency $/ 231775$ ?camid $=4 \mathrm{v} 1$

This title is available in InfoSci-Books, InfoSci-Business and Management, Business, Administration, and Management, Communications, Social Science, and Healthcare, InfoSci-Media and Communications, InfoSci-Select, InfoSci-Select, InfoSci-Business Knowledge Solutions - Books, InfoSciSocial Sciences Knowledge Solutions - Books, InfoSci-Select. Recommend this product to your librarian: www.igi-global.com/e-resources/library-recommendation/?id=1

\section{Related Content}

Internet Marketing and Consumers Online: Identification of Website Attributes Catering to Specific Consumer Intents in a Digital Paradigm Neha Jain, Vandana Ahuja and Y. Medury (2012). International Journal of Online Marketing (pp. 70-82). www.igi-global.com/article/internet-marketing-consumers-online/69979?camid=4v1a

Rhetoric of Seduction: From an Iconocratic Advertising to a Tautological Culture Paulo M. Barroso (2017). Advertising and Branding: Concepts, Methodologies, Tools, and Applications (pp. 45-64).

www.igi-global.com/chapter/rhetoric-of-seduction/175215?camid=4v1a

The Roles of Sports Sponsorship and Brand Management in Global Sports Marketing Kijpokin Kasemsap (2015). Emerging Trends and Innovation in Sports Marketing and Management in Asia (pp. 1-21).

www.igi-global.com/chapter/the-roles-of-sports-sponsorship-and-brand-management-in-globalsports-marketing/123864?camid=4v1a

Branding and Mobile: Revolutionizing Strategies

Yulia An and Kenneth E. Harvey (2019). Brand Culture and Identity: Concepts, Methodologies, Tools, and Applications (pp. 493-528).

www.igi-global.com/chapter/branding-and-mobile/213722?camid=4v1a 